\title{
IMPORTANCE OF EVALUATING AND SELECTING DEVELOPMENTALLY APPROPRIATE SOFTWARE FOR VERY YOUNG CHILDREN
}

\section{Mária KOŽUCHOVÁ-Miroslava VIŠŇOVSKÁ}

\begin{abstract}
This article presents theoretical background for the computer use in preprimary education. The authors of the article have established a set of teacher's competencies based on foreign sources in English language and the professional experience of the authors. These teacher's competencies are related to child-computer use in the teaching-learning process. This work was supported under KEGA grant No. 3/7127/09.
\end{abstract}

Key words: preprimary education, computers in the teaching-learning process, teacher's competencies.

\section{VÝZNAM HODNOTENIA A VÝBERU VÝVINOVO PRIMERANÉHO SOFTVÉRU PRE DETÍ PREDŠKOLSKÉHO VEKU}

\begin{abstract}
Abstrakt: Článok prezentujeme teoretické východiská výučby s počítačovou technikou v predprimárnom vzdelávaní. Autorky vychádzajú zo zahraničných skúseností edukácie, predovšetkým $z$ výskumov anglofónnych krajín. Na základe štúdia zahraničných prameňov a vlastných skúseností vytvorili súbor kompetencii pre učitel’ov predprimárneho vzdelávania vo vztahu $k$ výučbe podporovanej počítačovou technikou. Príspevok vznikol s podporou grantu KEGA 3/712709.
\end{abstract}

Kl'účové slová: predprimárne vzdelávanie, výučba s počítačom, kompetencie učitel.

\section{Úvod}

Informačno-komunikačné technológie majú svoje miesto vo vzdelávaní na všetkých stupňoch škôl už niekol'ko desiatok rokov. Tým, že sa technika stáva stále viac dostupnejšou, jej použitie sa rozširuje aj na proces výučby a dostáva sa k čoraz mladším det’om. Najmarkantnejšie sa tento posun prejavil $\mathrm{v}$ počítačovej technike, ktorá je prítomná už v predprimárnom vzdelávaní.

V zahraničí sa o problematike výučby s počítačom uskutočňuje odborný diskurz už niekol'ko desiatok rokov. Existujú výskumné štúdie, správy i publikácie dokumentujúce výsledky výskumných zistení, na základe ktorých vzdelávacie inštitúcie a organizácie publikujú návrhy a odporúčania pre rodičov, učitel'ov a iných pedagogických pracovníkov ako počítač využívat' tak, aby bol prínosom pre deti a proces učenia sa (napr. NAEYC, 1996; Bowman, B. T., Donovan, S. M., Burns, S. M., 2000; Becta, 2007). Súčasne s najnovším poznaním v oblasti interakcie diet'a - počítač - učitel' sa v zahraničí už dlhodobo poukazuje na celý rad nových kompetencií, ktorými potrebuje učitel' disponovat', aby bol efektívnym aktérom vo výučbovom procese s počítačom.
Štátny vzdelávací program pre predprimárne vzdelávanie (2008) počíta s prítomnostou počítačov $\mathrm{v}$ triedach materských škôl. Touto požiadavkou sa menia aj kompetencie učitel'a predprimárneho vzdelávania. Prinajmenšom sa rozširujú o nové kompetencie, ktoré súvisia s využívaním počítačov vo výučbe. Tie však neboli doposial' zadefinované. Vzniká situácia, že do už existujúcej pedagogickej praxe iba „pribudol“ nový artefakt - počítač. Pýtame sa: „Ako má učitel' s týmto novým artefaktom narábat' vo výučbe?" „Aké kompetencie (spôsobilosti) tento artefakt od učitel'a vyžaduje, aby bol ten následne využívaný ako didaktický nástroj?“1

Sledovanie odborného diskurzu $\mathrm{k}$ problematike $\mathrm{v}$ zahraničí nás priviedlo $\mathrm{k}$ zdroju, ktorý spĺn̆a naše kritériá a odpovedá na naše otázky. V prvej časti prezentujeme teoretické východiská, ktoré vychádzajú zo štúdia zahraničných prameňov a vlastných skúseností experimentálneho overovania využívania počítačov $v$ materských školách. Následne ponúkame hlbšiu kritickú analýzu hodnotenia a výberu vývinovo primeraného softvéru pre detí

\footnotetext{
${ }^{1}$ Počítač ako didaktický nástroj (NAEYC, 1996)
} 
predškolského veku. Tejto problematike sa v odbornej literatúre na Slovensku nevenuje náležitá pozornost'.

\section{Teoretické problematike \\ východiská \\ k skúmanej}

Najuznávanejšou vzdelávacou organizáciou, ktorá sa zameriava na výchovu a vzdelávanie detí od troch do ôsmich rokov, je v severoamerickom prostredí asociácia National Association for the Education of Young Children (NAEYC) (Národná asociácia pre výchovu a vzdelávanie malých detí - vol'ný preklad). V dokumente Developmentally appropriate practice (DAP), sú navrhnuté princípy pre „vývinovo primeranú prax“. Tento dokument bol široko akceptovaný a inkorporovaný do programov vzdelávania učitel'ov cez National Council for the Accreditation of Teacher Education (NCATE) (Národná rada pre akreditáciu vzdelávania učitel'ov - vol'ný preklad). Na základe dokumentu DAP asociácia vydala v roku 1996 vyhlásenie Technology and Young Children: Ages 3 through 8 (Technika a malé deti: od troch do ôsmich rokov), v ktorom deklaruje postoj $\mathrm{k}$ využívaniu techniky $\mathrm{v}$ edukácii detí do ôsmich rokov $\mathrm{v}$ zmysle akceptovania ich vývinových špecifík.

Postoj asociácie NAEYC k využívaniu techniky sa zakladá na premise, že technika (počítač) je nástroj, ktorý môže byt' na jednej strane využitý v prospech jeho používatel'ov, no na strane druhej môže byt' aj zneužitý podobne ako ktorýkol'vek iný nástroj. Preto NAEYC sa orientovala na pozitívny efekt učenia sa a rozvoj osobnosti diet’at'a. Vychádzajú z tvrdenia, že ak je technika (počítač) využívaná primerane s rozvojovými možnost'ami detí, vtedy má pozitívny vplyv na ich rozvoj. Zároveň to znamená, že technika (počítač) dopíňa a nie nahrádza známe tradičné aktivity a materiály ako sú knihy, experimenty, či hra.

$\mathrm{V}$ dokumente sú spracované návrhy a odporúčania ako využívat' techniku vo výučbe a akými schopnost'ami musia učitelia disponovat', aby mohli byt' uvedené praktické návrhy uskutočnitel'né. Pojem „technika“ (technology) sa v dokumente vzt'ahuje predovšetkým na počítačovú techniku (hardvér, softvér), ale zahŕňa aj telekomunikačné prostriedky a multimédiá (IKT) (podl'a NAEYC, 1996). Teoretickou platformou asociácie NAEYC sú sociokognitivistické teórie učenia sa, na základe ktorých asociácia vymedzuje aj schopnost' hodnotenia a výberu vývinovo primeraného softvéru.

\section{Schopnost' hodnotenia a výberu vývinovo primeraného softvéru}

Tá je v dokumente NAEYC definovaná nasledovne: „Učitelia musia venovat' čas hodnoteniu a výberu softvéru vo svetle princípov vývinu a učenia sa detí.. Výber vhodného edukačného programu je podobný výberu vhodných kníh pre deti - učitel' musi neustále posudzovat', čo je veku primerané, individuálne primerané a kultúrne primerané... Učitel má pri výbere softvéru aplikovat' rovnaké kritériá, aké by uplatnil pri výbere akéhokolvek iného učebného nástroja", uvádza NAEYC (1996). $\mathrm{V}$ dokumente sa na označenie vhodného softvéru pre deti používa pojem vývinovo primeraný softvér (developmentally appropriate software). Podl'a organizácie NAEYC je to taký program, ktorý ponúka možnosti na kolaboratívnu hru, učenie sa atvorivost' (1996). Vývinovo primeraný softvér má byt' vytvorený tak, aby:

- reflektoval svet detí, v ktorom žijú (napr. kultúrny kontext),

- umožňoval kreatívnu hru,

- umožňoval učenie sa, ktoré zapája vyššie poznávacie funkcie (syntézu, hodnotenie, tvorivost', kreativitu), riešenie problémov a konverzáciu,

- umožňoval det'om kontrolovat' proces učenia sa a dej prebiehajúci na monitore počítača,

- umožňoval opakovat' aktivity tak často, ako diet'a potrebuje,

- umožňoval experimentovat's variáciami,

- umožňoval kolaborovat' pri rozhodovaní,

- mohli diskutovat' s rovesníkmi a učitel'om o tom, čo diet'a objavilo a vytvorilo,

- podporoval rovnost' pohlaví, zobrazoval l'udí rôznych rás, rôzneho veku a schopností,

- zobrazoval pozitívnu sociálnu interakciu a hodnoty

- a nezobrazoval násilie.

Prečo sa na výber a hodnotenie softvéru kladie dôraz? Táto požiadavka vznikla z dôvodu množstva komerčného edukačného softvéru, ktorý je v súčasnosti na trhu. Ako uvádza NAEYC (1996), väčšinu komerčného edukačného softvéru nie je vhodné zaradit' do výučby. Aj ked' je tento argument viac ako desat'ročie starý, aj novšie zdroje ho potvrdzujú. U nás, napríklad, sa touto problematikou zaoberá Kalaš a kol. (In: Asociácia..., 2003), citujeme: „navrhovatelia softvéru venujú často viac 
pozornosti používatel'skému prostrediu a vzhl'adu“. Počítačový program vytvorený marketingovými programátormi nemusí spíňat' všetky požiadavky na kvalitu a vhodnost' vzhl'adom na vekové osobitosti detí predškolského veku, ani korešpondovat' s obsahom a ciel'mi vzdelávania. Navyše, nie každý program, ktorý má v názve slovo vzdelávací, edukačný, didaktický, či interaktívny, je ním aj v skutočnosti. Preto je v kompetencii učitel'a hodnotit' a vyberat' edukačný softvér, čo však v praxi môže narazit' na viaceré problémy.

\section{Úskalia hodnotenia a výberu edukačného softvéru}

Za jeden $\mathrm{z}$ hlavných faktorov, ktorý má značný vplyv na hodnotenie a výber edukačného softvéru považujeme poznanie problematiky interakcie diet'a - počítač - počítačový softvér. Odborný diskurz v zahraničí a závery z výskumov ukazujú, že nie každý spôsob využitia počítača je pre deti predškolského veku vhodný, a že nie každý typ softvéru je vhodné zaradit' do výučby v materskej škole.

Pripodobnenie výberu softvéru $\mathrm{k}$ výberu kníh, ako to uvádza NAEYC, je napríklad podl'a Stephen a Plowman (2002) pomýlené, pretože prehliada inú úlohu počítača ako sprostredkovatel'a obsahu a nepripúšt’a rozsah interakčných vzorcov, ktoré poskytujú rôzne typy počítačových programov (s. 15). Výskumy dokazujú, že softvér zameraný na precvičovanie (drill and practice software) má nízky pozitívny efekt na kreativitu a vyššie úrovne myslenia oproti iným typom softvéru, ako sú otvorené programy (napr. Logo) (Haugland, 1992 In: Clements - Sarama, 2003, Healy, 1998). V sociálnej oblasti tieto programy na jednej strane podporujú schopnost' striedat' sa pri počítači, no na druhej strane podnecujú sút'aživost' medzi det'mi (Clements, Nastasi, 1992 In: Clements - Sarama, 2003). Podl'a Clements Sarama (2003) pri sledovaní otvorených programov ako Logo sú výsledky pozitívne tak v kognitívnych, ako aj v sociálnych kompetenciách, Logo môže pomôct' det'om chápat' vzt'ahy vgeometrii a konštruovat' poznatkové siete (na rozdiel od mechanického osvojovania), v sociálnej oblasti tieto programy podporujú kolaboráciu medzi det'mi, ktorá je charakterizovaná takými kompetenciami ako sú stanovenie ciel'a, plánovanie, vyjednávanie, a vyriešenie problému. (Podrobnejšie sme o vzt’ahu medzi typom softvéru a dimenziami rozvoja osobnosti diet’at'a referovali v príspevku
Osobnost' diet'at'a predškolského veku a edukačný softvér na konferenci $v$ Levoči (16.4.2009). Podl'a Bowman, Donovan a Burns (2000) učitel' má pri výbere softvéru pamätat' na to, že kým softvér na precvičovanie pomáha v zlepšení len základných zručností, iné typy softvéru sú hodnotnejšie, pretože rozvíjajú vyššie úrovne myslenia a poznania. $Z$ našich zistení vyplýva, že problematiku vzt’ahu medzi typom softvéru a jeho vplyvom na rôzne dimenzie rozvoja osobnosti diet’at’a u nás učitelia nepoznajú. Poznanie tohto vzt'ahu považujeme za dôležitú súčast' kompetencie hodnotenie a výber edukačného softvéru, a je esenciálne v schopnosti identifikovat' vývinovo primeraný softvér.

Ďalším $\mathrm{z}$ faktorov, ktorý ovplyvňuje uskutočňovanie hodnotenia a výberu edukačného softvéru učitel'om je „nedostatok času“ (Becta, 2007). Túto skutočnost' zistila anglická vzdelávacia organizácia Becta. Učitelia, podrobení výskumu, uvádzali viacero dôvodov, predovšetkým však nedostatok času na výber vhodného softvéru a podl'a zistení organizácie je práve výber a hodnotenie softvéru kritickým. Je kritickým práve preto, že učitel'om $\mathrm{k}$ doterajším kompetenciám „pribudli“ nové kompetencie, ktoré súvisia s využívaním počítačov vo výučbe. Jednoducho povedané, učitelia majú viac práce za rovnakých podmienok.

U nás je najmarkantnejším faktorom ovplyvňujúcim konatívnu rovinu kompetencie samotný proces zavádzania počítačov do materských škôl, ktorý sa sústredil len na technickú stránku implementácie počítačov a vynechal $\mathrm{z}$ tohto procesu doterajšie poznanie problematiky i učitel'a ako realizátora výučby. Doterajšie poznanie ukazuje tenkú hranicu medzi pozitívami a negatívami počítačovej techniky vo výučbe a výskumy dokazujú jej celkový vplyv (pozitívny i negatívny) na rozvoj osobnosti diet'at'a (Healy, 1998, Cordes, Miller, 2000, Clements - Sarama, 2003). Náhodný výber softvéru je preto nežiaduci, no pre učitel'ov doposial' neboli definované úlohy a kompetencie a nebolo im umožnené stat' sa kompetentnými profesionálmi vdidaktickej rovine využívania počítačovej techniky (chýbajú publikácie, odporúčania, odborná asistencia). Nevidíme profesionalitu učitel'a $\mathrm{v}$ technickom zabezpečení výučbového procesu, ale $\mathrm{v}$ jeho didaktickom zabezpečení, t.j. v poznaní didaktického využitia počítača a hlbokého poznania problematiky interakcie diet'a - počítač - počítačový softvér. 


\section{Záver a odporúčania}

Schopnost' hodnotenia avýberu vývinovo primeraného softvéru si vyžaduje od učitel'a hlbšie poznanie problematiky vzt'ahu diet'a počítač - počítačový softvér. Koncept vývinovo primeraný softvér je v našich podmienkach nový a v príspevku sme sa pokúsili zadefinovat' kritéria na jeho ohraničenie. U nás chýbajú vzdelávacie inštitúcie a organizácie, ktoré by načrtnuté otázky výskumne riešili a následne reagovali na potreby učitel'ov, na ktorých zostáva plánovanie a realizácia výučbového procesu v materskej škole. Je nutná vyššia angažovanost' vzdelávacích inštitúcií a spolupráca pedagogických fakúlt. Za vel'mi potrebné považujeme hodnotiace posudky na edukačný softvér pre deti predškolského veku. Takéto hodnotenie by učitel'om pomohlo pri výbere vhodného edukačného softvéru.

Preto odporúčame:

o podnietit' diskusiu o kompetenciách učitel'a predprimárneho vzdelávania vo vzt’ahu k počítačovej technike,

○ vytvorit' kategorizáciu vývinovo primeraného softvéru, pretože sa domnievame, že by bola vhodným nástrojom pre učitel'ov $\mathrm{v}$ procese plánovania výučby $v$ materskej škole a v orientácii sa v spleti komerčného edukačného softvéru,

○ po úpravách uplatnit' niektoré závery $\mathrm{z}$ dokumentu aj $\mathrm{v}$ našich podmienkach aj napriek tomu, že dokument vznikol v americkom prostredí a má určité limity.

\section{Literatúra}

[1] Asociácia projektu Infovek: Štátny program Budovanie informačnej spoločnosti Využitie IKT technológii a siet'ových platforiem novej generácie vo vzdelávaní. Klasifikácia edukačného softvéru. 2003, dostupné online http://edi.fmph.uniba.sk/ kalas/Vyucba/TPS1/ed usoftver.doc

[2] Bowman, B. T., Donovan, S. M., Burns, S. M.: Eager to learn: Educating Our Preschoolers. Committee on Early Childhood Pedagogy, Commission on Behavioral and Social Sciences and Education, National Research Council. National Academy Press, Washington, DC. 2000. ISBN 0-309-06836-3, dostupné online $\quad$ http://books.nap.edu/openbook.php ?record id=9745\&page $=\mathrm{R} 1$
[3] Cordes, C., Miller, E. (Eds.). Fool's Gold: A Critical Look at Computers in Childhood. Alliance for Childhood. 1999, dostupné online http://www.alliancefor childhood.org/projects/computers/computers_rep orts_fools_gold_contents.htm

[4] Clements, D., Sarama, J.: Strip Mining for Gold: Research and Policy in Educational Technology - A Response to "Fool's Gold". AACE Journal. Norfolk, VA: AACE. 11,1, pp. 769, 2003, dostupné online http://www.editlib .org/index.cfm/files/paper 17793.pdf?fuseaction =Reader.DownloadFullText\&paper $\mathrm{id}=17793$

[5] Healy, M. J.: Failure to connect: how computers affect our children`s minds - and what we can do about it. New York: Touchstone, 1998, 350 s., 1st edition. ISBN 0-684-83136-8

[6] National Association for the Education of Young Children (NAEYC). Technology and Young Children - Ages 3 through 8. A position statement. $\quad 04 . \quad 1996$, dostupné online http://www.naeyc.org/about/positions/pdf/PSTE

\section{CH98.PDF}

[7] Research report: Impact of ICT in schools: a landscape review.2007. Becta. 2007, pp. 93, Publication ID: BEC1-15455, dostupné online: http://publications.becta.org.uk/ display.cfm?resID $=28221$ \&page $=1835$

[8] Stephen, C., Plowman, L. 2002. ICT in Pre-school: A „Benign Addition“? A review of the literature on ICT in pre-school settings. In Journal of Computer-Assisted Learning. 19, 2, 2002, s. 145-158. ISSN: 1365-2729, dostupné na internete: http://www.ioe.stir.ac.uk/staff/docs/ plowman-benignaddition.pdf

Prof. PhDr. Mária Kožuchová, CSc.

Katedra predškolskej a elementárnej pedagogiky PdF UK v Bratislave

85106 Bratislava, Račianska 59 e-mail: kozuchova@gmail.com
Mgr. Miroslava Višňovská
Katedra predškolskej a elementárnej
pedagogiky PdF UK v Bratislave
85106 Bratislava, Račianska 59
e-mail: visnovska@fedu.uniba.sk 